\title{
Were climatic changes a driving force in hominid evolution?
}

\author{
J. CHALINE ${ }^{1}$, A. DURAND ${ }^{1}$, A. DAMBRICOURT MALASSÉ ${ }^{2}$, B. DAVID ${ }^{1}$, F. \\ MAGNIEZ-JANNIN ${ }^{1}$ \& D. MARCHAND ${ }^{1}$ \\ ${ }^{1}$ UMR CNRS 5561 et Laboratoire de Préhistoire et Paléoécologie du Quaternaire de \\ l'EPHE, Université de Bourgogne, Centre des Sciences de la Terre, 6 bd. Gabriel, 21000 \\ Dijon, France \\ ${ }^{2}$ Institut de Paléontologie humaine du Muséum National d'Histoire Naturelle de Paris \\ (UMR CNRS 9948), 1 rue R. Panhard, 75013 Paris, France \\ (e-mail: jchaline@u-bourgogne.fr)
}

\begin{abstract}
A comparison of externalist and internalist approaches in hominid evolution shows that the externalist approach, with its claim that climate was responsible for the appearance of bipedalism and hominization, now seems to be ruled out by the biological, palaeogeographical, palaeontological and palaeoclimatic data on which it was based. Biological data support the embryonic origin of cranio-facial contraction, which determined the increase in cranial capacity and the shift in the position of the foramen magnum implying bipedalism. In the internalist approach, developmental biology appears as the driving force of hominid evolution, although climate exerts a significant influence and was involved in the following ways: (1) in the prior establishment of ecological niches that allowed the common ancestor to become differentiated into three subspecies; (2) by dividing up the area of distribution of species, resulting in the present-day subspecies of gorillas and chimpanzees; (3) by facilitating relative fluctuations of the geographical areas of distribution of the various species, particularly the spread of australopithecines across the African savanna from north (Chad, Ethiopia) to south (South Africa); (4) by determining adaptive geographical differentiations among Homo erectus and Homo sapiens (pigmentation, haemoglobin, etc.).
\end{abstract}

Climate, as a factor of the environment, exerts a major influence over the geographical distribution of species and subspecies, and over their adaptation to their environment, although there are wide variations in the way it affects different groups. The living world is organized on a hierarchical basis, and the gearing ratios between the different levels may vary substantially. This is the case with hominids, where changes are small at the molecular level (King \& Wilson 1975; Hixson \& Brown 1986; Miyamoto et al. 1987, 1988; Hayasaka et al. 1988; Ueda et al. 1989; Gonzales et al. 1990; Sibley et al. 1990; Bailey et al. 1991, 1992; Horai et al. 1992; Perrin-Pecontal et al. 1992; Goodman et al. 1994), larger at the chromosomal level (Chiarelli 1962; De Grouchy et al. 1972; Stanyon \& Chiarelli 1981, 1982, 1983; Yunish \& Prakash 1982; Marks 1985, 1993; Dutrillaux \& Couturier 1986; Dutrillaux et al. 1986; Godfrey \& Marks
1991; Matera \& Marks 1993) and greatly amplified at the morphological level (Dambricourt Malassé 1987, 1988, 1993, 1996; Chaline 1994, 1998; Deshayes, 1997). These differences constitute the human paradox.

The questions raised are about the precise role of climate in distinct aspects of hominid evolution and the way climate affects the different levels of organization of the living world. There are currently two contrasting views of the origin and evolution of the higher apes and of humankind as related to the role of climate. One is an externalist approach (Coppens 1986, 1994), whereas the other is an internalist approach (Chaline 1994, 1998; Chaline et al. 1998).

The aim of this paper is: (1) to present the externalist and internalist approaches; (2) to put forward explanatory models of evolution within a palaeoclimatic and palaeoecological frame- 
work; (3) to test the exact role of climate as a driving force behind human evolution (when, where and how?), and thus to test the two opposing hypotheses, the externalist v. the internalist approach.

The externalist approach: climate as the major driving force behind human evolution

The externalist approach (Coppens 1986, 1994) is a theory in which climate is seen as the principal driving force behind human evolution, alongside tectonics. The theory is based on two observations: (1) the present-day distribution of chimpanzees and gorillas covers all of the tropical forest regions of Africa, but terminates with virtually no overlap at the great tectonic trough of the East African Rift Valley; (2) the sites of hominid fossils that are more than $3 \mathrm{Ma}$ old lie to the east of the Rift Valley.

Coppens deduced from this that panids and hominids were segregated geographically by the tectonic crisis some $8 \mathrm{Ma}$ ago that caused the Rift Valley floor to collapse and raised the western lip of the Western Rift, creating an $8000 \mathrm{~m}$ barrier between the summits and the bottom of Lake Tanganyika. 'The great initial province was split in two. The west remained humid and the forests and woodlands were preserved, while the east became increasingly arid with ever more sparse savanna. The common ancestor population of Panids and Hominids was therefore divided into a larger western and a smaller eastern population. It is tempting to imagine that the segregation was the cause of the divergence between the two groups: the western descendants continued to adapt to life in an arboreal environment and formed the Panids while the eastern descendants of the same ancestors "invented" new mechanisms suitable for life in an open environment and gave rise to the Hominids' (Coppens 1994, p. 67). Coppens considered that the earliest forms of australopithecines were more confined to arboreal environments than the more recent species (Coppens 1986, p. 232). Man, for his part, is without doubt a pure product of aridity, which Coppens termed the 'Omo event' (Coppens 1994 , p. 71 ).

This theory asserts that the diversity currently observed among hominids results from tectonic and subsequently climatic events. Climate is seen therefore as a major force in human evolution. The great weakness of the externalist approach is that it provides no biological mechanism to account for the substantial changes in body shape.
The internalist approach: the ontogenetic mechanism

This is a radically different theory based upon biological data, especially upon the ontogenetic mechanism. This theory was later explored by Delattre \& Fenart (1954, 1956, 1960), who analysed the ontogenesis of higher ape and human skulls and showed that they underwent occipital and facial contraction. These major stages of cranio-facial contraction are a wellknown phenomenon in primates, alternatively termed 'flexure of the skull base' or 'occipital shift' (Deniker 1885; Anthony 1952).

The internalist approach is supported by the data of ontogenetic development, which was completely overlooked in the so-called Synthetic Theory of Evolution during the 1940s (Devillers \& Chaline 1993). Such an approach links genetics to morphogenesis through developmental biology. It has given rise to stimulating research (Gould 1977; Raff \& Kauffman 1983; Devillers \& Chaline 1993; Raff 1996 (for synthesis); McGinnis \& Kuziora 1997; Pennisi \& Roush 1997).

This approach has been taken up more recently by Deshayes $(1986,1991)$, Dambricourt Malassé $(1987,1988,1996)$ and Deshayes \& Dambricourt Malassé (1990). Dambricourt Malassé (1987) discovered and proved that cranio-facial contraction is a embryonic phenomenon that is clearly visible in the mandible, and that the living and fossil lower jaws retain the range of contraction. She also demonstrated that primate evolution can be summarized as six 'fundamental ontogenies', because of their embryological origin, corresponding to successive body plans or bauplans, resulting from six major phases of cranio-facial contraction: (1) prosimians; (2) monkeys apes; (3) great apes; (4) australopithecines; (5) Homo; (6) Sapiens. Recent morphometric studies on the skull (Chaline et al. 1998) have shown that the modern human form is not significantly different from the earlier forms of the genus Homo. Thus we do not retain here the 'Sapiens' bauplan (Fig. 1).

The morphological areas defined by these bauplans are exploited by more-or-less numerous speciation events (Fig. 2). Obviously, comparisons between the great ape skull plan, which is contemporary with Homo sapiens, and the two fossil hominids skull plans (Australopithecus and Homo), which extend over time, are a working hypothesis and not an evolutionary model in the strict sense, insofar as we assimilate the living great apes to their Tertiary ancestors.

This internalist approach views development 


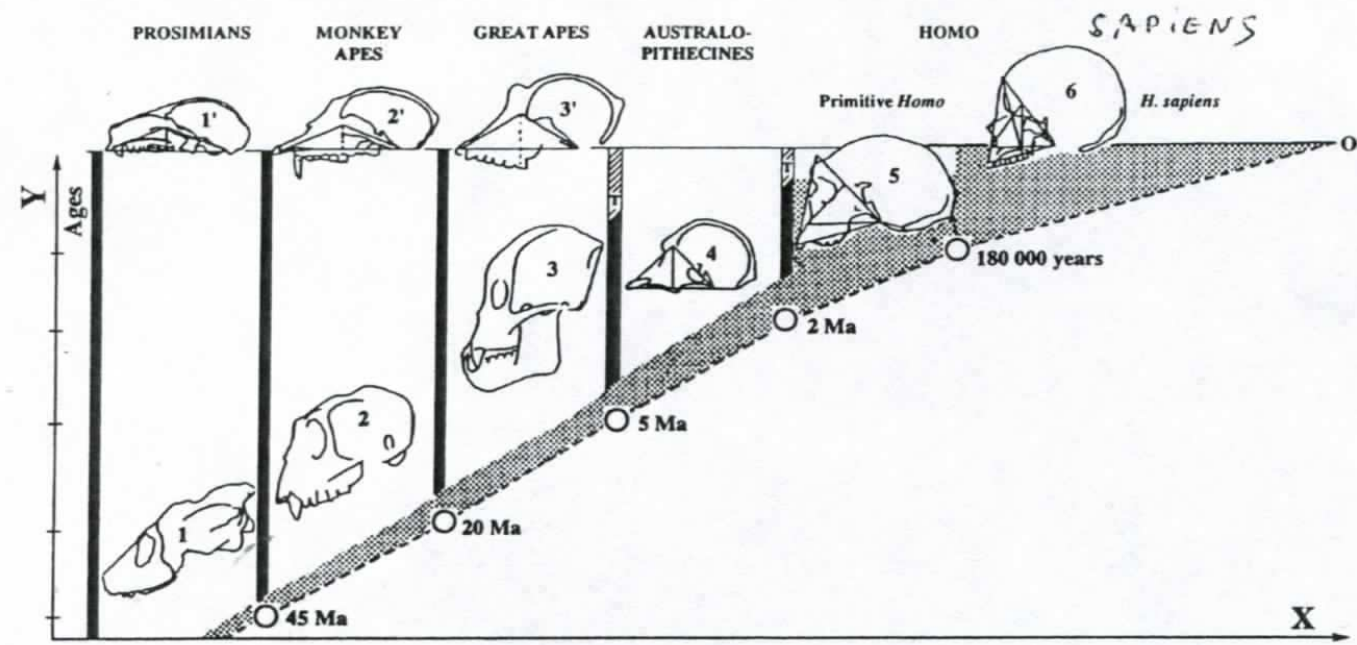

Fig. 1. Phylogeny of embryonic basicranial-facial contraction in primates (after Dambricourt Malassé 1996). X, range of contraction; Y, geological time. 1, Adapiform; 1', Lemuriform; 2, Mesopithecus; 2', Cercopithecus; 3, Proconsul africanus; 3', Gorilla; 4, Australopithecus africanus; 5, Homo erectus; 6, Homo sapiens. T, extinction. Explanation: the range of embryonic contraction is unchanged from Adapiforms (1) to living lemurs ( $1^{\prime}$ including lorises and tarsiers). However, it increases between Adapiforms and Homo. Each column represents one fundamental ontogeny. Diversity occurs in each: in terms of range Tarsius fits in with the prosimians and not the simians, and similarly Hylobates fits in with the simians and not the great apes. The names above the figure correspond to the five bauplan names.

heterochronies and mutations of regulator genes as the engines of morphological change, and especially of the cranio-facial contractions that punctuate the evolution of the higher apes and hominids. From great apes to modern man numerous heterochronies (hypermorphosis, hypomorphosis and post-displacements) have occurred during ontogeny (Chaline et al. 1998), allowing (1) the acquisition of permanent bipedalism of Australopithecus and Homo, (2) the increased cranial capacity of primitive forms of Homo (habilis, ergaster, rudolfensis, erectus, heidelbergensis and neanderthalensis) and (3) the disappearance of simian characters associated with renewed increase in cranial capacity in Homo sapiens.

Analysis of the neotenic mechanism in the axolotl (Ambystoma mexicanum) provides an eloquent example linking genetic regulation (Humphrey 1967; Voss 1995) with environmental conditions (Norris \& Gern 1976). In this instance, environment, through temperature, is instrumental during early larval stages in activating or inhibiting genes that control the selection of the most effective morphologies within a fairly broad spectrum of possibilities.

The genes responsible for heterochronies, and more particularly Hox genes (Dollé et al. 1993; Carroll 1995; McGinnis \& Kuziora 1997; Pennisi \& Roush 1997; Meyer 1998), or other regulatory genes, may explain the origin of cranio-facial contractions in hominids and certain human deformities, and thus provide a biological solution to the human paradox of the $1 \%$ genetic divergence versus the large morphological difference between humans and chimpanzees.

The internalist approach reflects the preeminent role of the ontogenetic mechanism (Chaline 1994, 1998). The next step is to examine the climatic data that reflect the external constraints on biological systems.

\section{Climatic patterns through time}

The pattern of climates in Africa is controlled primarily by the position of the equator and the tropics (climatic gradients perpendicular to the equator). Ascending air masses in the equatorial zone lead to cloud formation. The next factor in climate distribution is the presence of oceans on either side of the continental landmass, which provide the water vapour necessary for cloud formation (gradients parallel to the equator). Only then does orography come into play by locally altering the gradients parallel and perpendicular to the equator. The present-day situation has arisen very gradually since the time the South Atlantic opened up some $130 \mathrm{Ma}$ ago and Africa wheeled round as it drifted more 


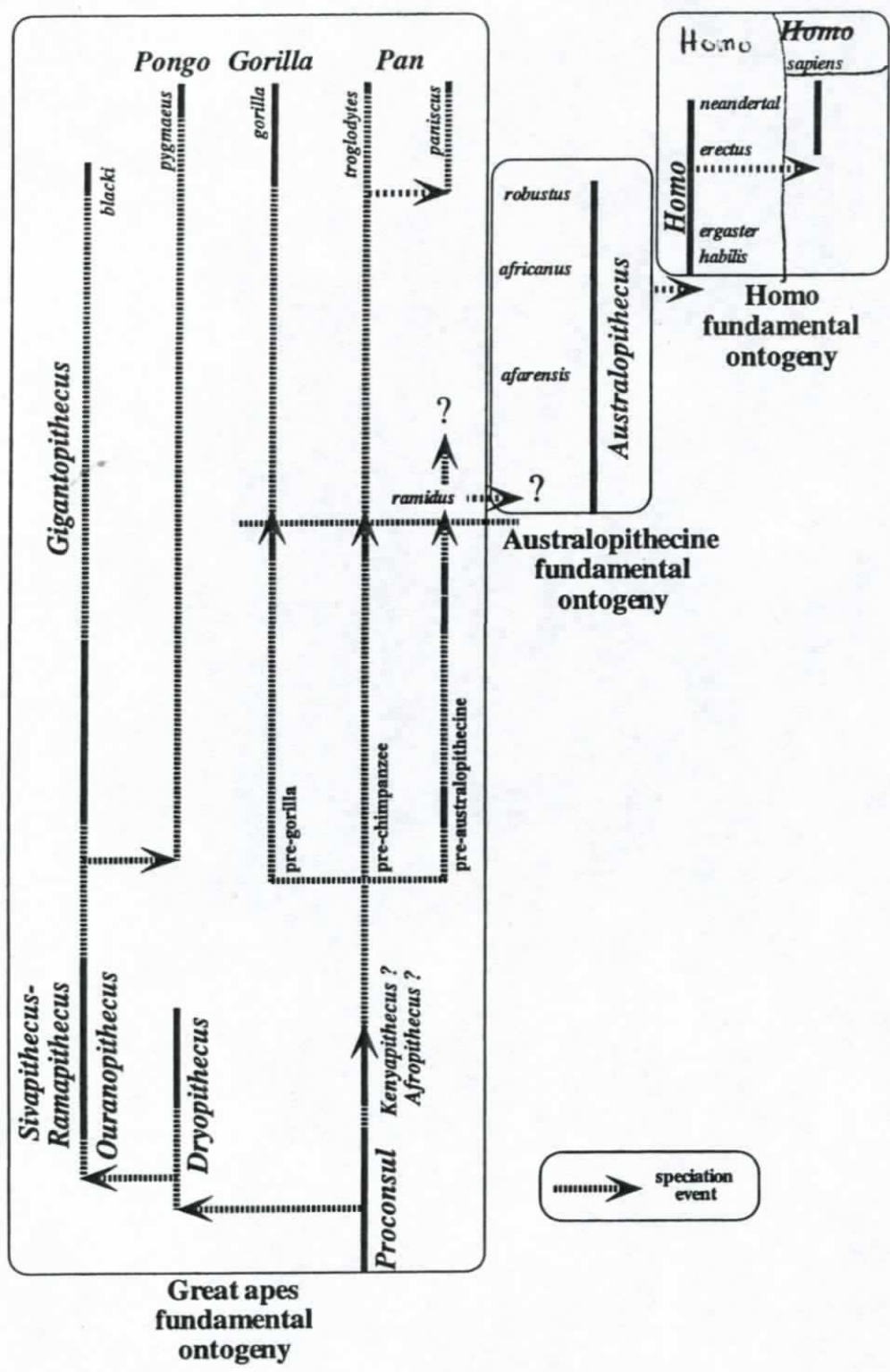

Fig. 2. Phylogenetic diagram showing relationship patterns with regard to all the palaeontological and ontogenetic data. Speciations occur by punctuation, and several lineages, such as australopithecines and early human, seem to undergo gradual evolutionary changes (continuous lines represent the fossil record). The last three fundamental ontogenies of primates ('great apes', 'Australopithecines', and 'Homo') are shown. The 'great apes' bauplan has been diversified into a great many species.

than $3000 \mathrm{~km}$ northward (Scotese et al. 1988). At $15-20 \mathrm{Ma}$ the situation was already very similar to the present-day situation and was in no way related to the formation of the Rift Valley.

This geographical pattern of climates underwent many large changes, first, because Africa has drifted relative to the equator, which lay $5^{\circ}$ further north about $10 \mathrm{Ma}$ ago (Scotese et al. 1988), but also because of changes in atmospheric circulation. In Late Miocene time tropical North Africa experienced at least four episodes of substantial climatic deterioration 


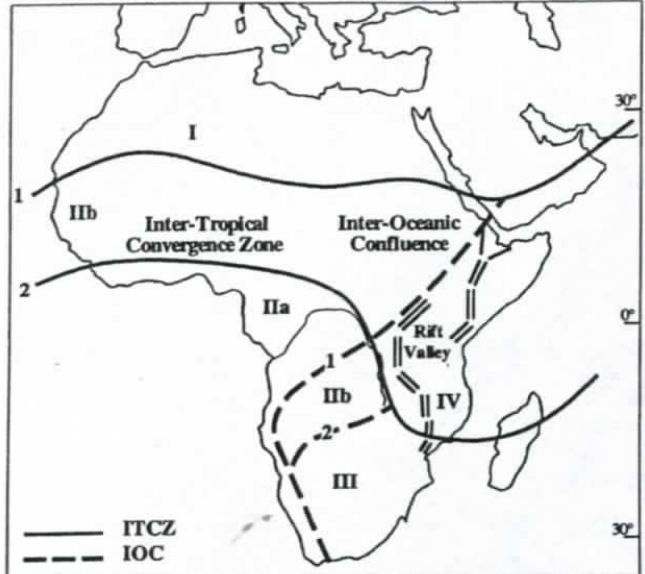

Fig. 3. Schematic and hypothetical geographical distribution of climates and environments in Africa between $23 \mathrm{Ma}$ and Present. ITCZ, Inter-Tropical Convergence Zone; IOC, Inter-Oceanic Confluence; 1 , when the sun is over the Tropic of Cancer; 2 , when it is over the Tropic of Capricorn; I, area of continental trade winds; II, area of Atlantic monsoon; IIa, area of permanent Atlantic monsoon; IIb, area of seasonal Atlantic monsoon; III, area of Indian Ocean trade winds; IV, area of East African monsoons. The equator was $7^{\circ}$ more northerly at $23 \mathrm{Ma}, 5^{\circ}$ at $10 \mathrm{Ma}$ and $2^{\circ}$ at $6 \mathrm{Ma}$ (after Scotese et al. 1988).

leading to aridity, the last at the end of Miocene time (about 6-5.3 Ma) coinciding with a very distinct cooling of the Atlantic (Diester-Haass \& Chamley 1982; Sarnthein et al. 1982). Schematically, since the work by Chudeau (1921), it has been accepted that extensions of the arid Sahara zone are related in part to a reduced summertime advance of the front of the Inter-Tropical Convergence Zone (ITCZ; Fig. 3), which may even remain blocked in the Southern Hemisphere. The inter-Oceanic Confluence (N-S) coincides to some extent with the northern part of the Rift Valley (IOC; Fig. 3).

From Late Pliocene time (c. $3.2 \mathrm{Ma}$ ) general atmospheric circulation changed radically, for geodynamic reasons. Events such as the closure of the Panama isthmus, the opening of the Bering Straits and mountain building in northwest America and Asia are thought to have been decisive factors, in conjunction with variations in planetary orbit, in triggering the Northern Hemisphere ice ages (Ruddiman \& Raymo 1988; Berger 1992; de Menocal 1995). For recent times, when chronology is relatively precise, it is now known that changes occur suddenly. After the last glacial maximum, it is thought that the arid zone extended several hundred kilometres further south on three occasions between about 19 and $15 \mathrm{ka}{ }^{14} \mathrm{C}$ BP, each episode lasting only 500-1000 a (Durand 1995). The dense humid forest became fragmented and mountain biotopes spread as a result of the fall in temperatures (Maley 1987).

Against this general context we will examine below the impact of climate on: the diversification of the common ancestor, the formation of subspecies and species, the geographical distribution of the different species and the diversity among present-day humans. Chromosomal data must be introduced here that have not yet been included in the general scheme of hominid evolution.

\section{Chromosomal data}

A major advance in chromosome research was the development of R-banding and G-banding techniques. Opinions differ about the role of heterochromatin. Dutrillaux \& Couturier (1986) considered that the chromosome data from primates provide no evidence either for positional effects or that alterations in heterochromatin influence gene expression. This idea is materialized at the phylogenic level by two equally feasible dichotomic hypotheses entailing acceptance of three convergences or reversions, but a third hypothesis, where each rearrangement is regarded as unique, implies complex populational evolution (Dutrillaux \& Richard, 1997).

By contrast, Stanyon \& Chiarelli (1982), as well as Marks (1993), have argued that genes can be (1) repressed by placing them in, or near, blocks of heterochromatin, or (2) activated by a shift in their position away from heterochromatin regions. They set great store by active regions detected by Ag-NOR (silver nitrate) type methods and this has repercussions for phylogeny. They concluded that common derived karyological features indicate that Gorilla and Pan shared a common descent after the divergence of Homo. The distribution of heterochromatin at the tips of the chromosomes of gorillas and chimpanzees was confirmed by Marks (1993), suggesting a phylogenetic association between those two taxa.

\section{A trichotomic chromosomal model}

The common ancestral chromosome formula of all these species can be reconstructed by deduction. The reconstruction is based on the principle that if two, three or four species share a common chromosome, it is likely that some common ancestor transmitted it to all of them. This is the simplest relationship. We may also 


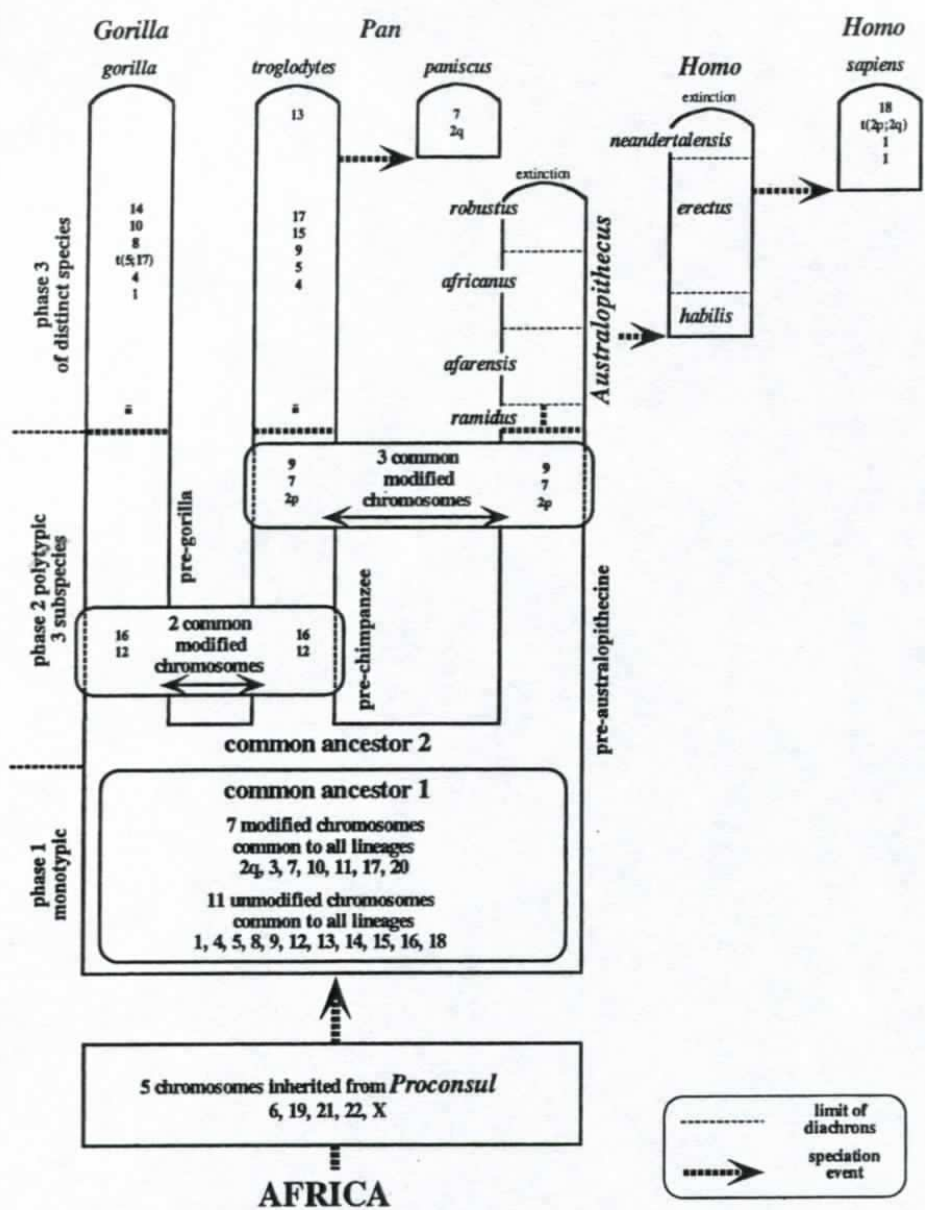

Fig. 4. Trichotomic chromosomal model incorporating palaeontological and ontogenetic data. This model explains the distribution of chromosome formulae of living species and proposes a solution for shared PanHomo, Gorilla-Pan apomorphic rearranged chromosomes and the absence of Gorilla-Homo apomorphic chromosomal features. After a monotypic phase accounting for chromosomal apomorphies 2, 3, 7, 10,11, 17 and 20 , the common ancestor must have become polytypic and divided into three subspecies: pre-gorilla, prechimpanzee and pre-australopithecine. Some $5 \mathrm{Ma}$ ago the three subspecies produced the three extant and fossil genera: Gorilla, Pan and Australopithecus. About $2 \mathrm{Ma}$ ago the Homo lineage derived from Australopithecus to give primitive man (Homo erectus), and around $0.18 \mathrm{Ma}$ ago modern humans (Homo sapiens). The figures refer to chromosomes rearrangements.

take the view that two identical chromosomal changes occur in the same way on the same chromosome in two related species derived from an ancestral form. This is statistically far less likely, although it is possible by convergence.

We have attempted to reconstruct the chronology of the formation of the various chromosomes and the successive events that marked the history of the family (Chaline et al. 1991, 1996) (Fig. 4).

Among anthropoid apes, the group with the most primitive chromosomal formula is logically the one that branched off earliest in the family history. This is the orang-utan group, which does not share the seven derived specific mutant chromosomes (2q, 3, 7, 10, 11, 17 and 20) of the common ancestor because it emigrated to Asia, where it has been cut off from the African branch for more than $10 \mathrm{Ma}$ (Andrews \& Cronin 1982; Lipson \& Pilbeam 1982; Simons 1989). It has been relatively stable from the chromosomal point of view, only two new chromosome mutations having occurred since that time.

After the separation of the orang-utan lineage, 


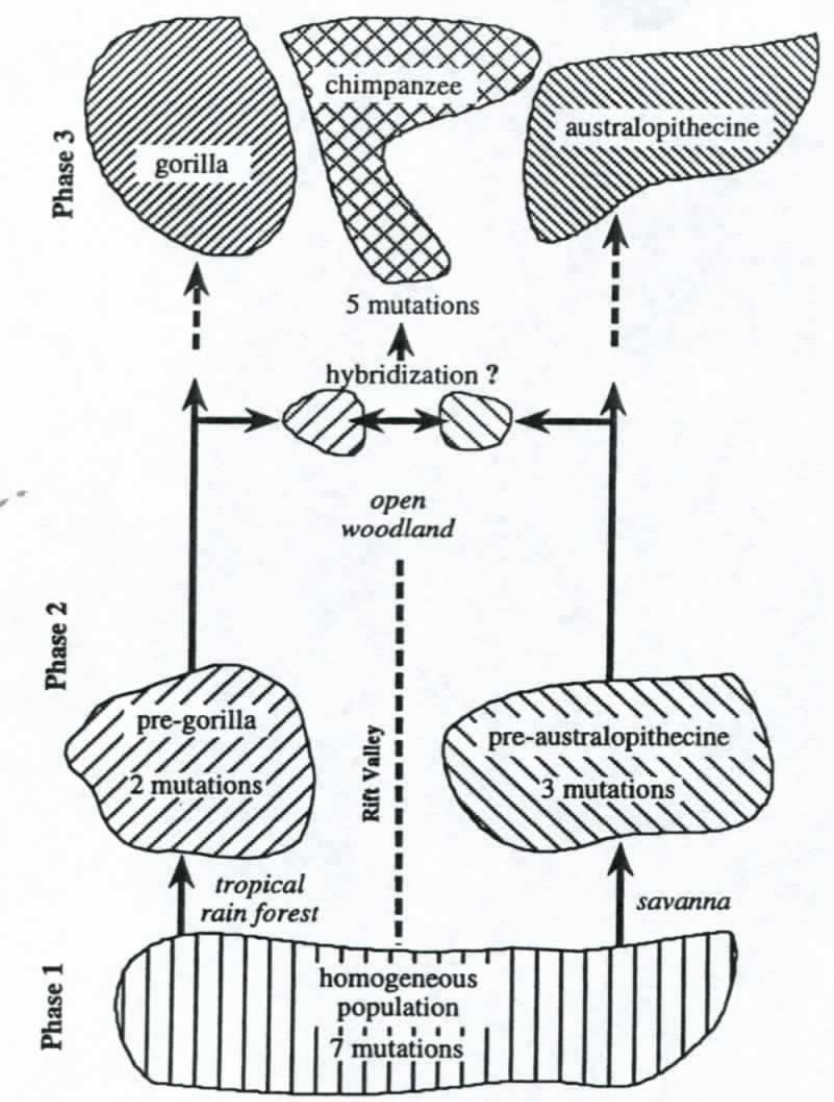

Fig. 5. Dichotomic model explaining the distribution of chromosomes in living species. This most parsimonious model suggests that after the monotypic phase, the common ancestor split into a polytypic phase with two subspecies (pre-gorilla and pre-australopithecine), and that the populations from the two subspecies interbred to produce the third, hybrid, subspecies (the pre-chimpanzees).

the common ancestral lineage of the three extant genera, chimpanzees, gorillas and humans, remained in Africa. This phase corresponds to the 'common ancestor' implied by genetic similarities. That there was a common ancestor is irrefutably shown by the formation of seven specific mutant chromosomes ( $2 \mathrm{q}, 3,7,10,11,17$ and 20) and by the retention of 11 non-mutated common chromosomes $(1,4,5,8,9,12,13,14$, 15,16 and 18) inherited by the three living species.

The occurrence of seven characteristic mutant chromosomes found in the gorilla, chimpanzee and human descendants implies that the common ancestor was a single monotypic species, not divided into subspecies. Genetic pooling as a result of interbreeding produces a fairly even spread of chromosome variety, including chromosomal variations that appear in isolated individuals. This first part of the history of the common ancestor corresponds to what we shall term the 'first homogeneous common ancestor phase' (Fig. 4).

Thereafter, the common ancestor diversified and the lineages separated, leading to the gorilla, chimpanzee and humans. This divergence raises a complex populational problem related to the distribution of five new mutated chromosomes.

It is reported that chimpanzees and humans share three mutated chromosomes (2p, 7 and 9) that gorillas do not have. Conversely, chimpanzees and gorillas share two other specific mutated chromosomes (12 and 16) not found in humans. In other words, chimpanzees share three common mutated chromosomes with humans and two common mutated chromosomes with gorillas. But gorillas share no special rearrangements with humans! This position is 
inexplicable by the standard hypothesis of a split into two branches (dichotomic model) leading to the gorilla-chimpanzee on one side and to humans on the other, as suggested by Marks (1993).

There is, however, a possible solution to the puzzle: the 'second heterogeneous common ancestor phase' (Fig. 4). To explain this major paradox, it must be supposed that at a certain time in their history, after the first undifferentiated phase, the ancestors of chimpanzees and gorillas were able to interbreed and acquire two new chromosome mutations they alone possessed, and not humans. This accords with the suggestion of Smouse \& Li (1987) 'that the ancestors of all three taxa were still conspecific' (see also Pruvolo et al. 1991).

However, it must also be accepted that for some time, perhaps different from the first period, the ancestors of chimpanzees and humans were able to interbreed and to incorporate three new chromosomal mutations into their genetic constitution, possessed by them alone and not gorillas. The fact that the ancestors of gorillas and humans do not share exclusive mutations in their chromosomal formulae implies that they did not at that time have contacts allowing hybridization. They were geographically isolated.

This model introduces australopithecines as a missing link between the common ancestor and the human lineage proper. They are never considered by chromosome specialists for the obvious reason that, being extinct, their chromosomes are unknown. But as they formed a necessary intermediate stage, they must be included in the model. By deduction, the chromosomal formula of the extinct pre-human form Australopithecus can be evaluated fairly accurately, except for the four chromosomes that were rearranged after genetic isolation of the species (ch $1 / 1 /$ fusion of $2 p-2 q / 18$ ).

\section{A dichotomic chromosomal model}

A further possible dichotomic model suggests that after the first common phase, two subspecies, pre-gorillas and pre-australopithecines became geographically separated and chromosomally differentiated (Fig. 5). Only then did two small populations of each subspecies meet and form the pre-chimpanzee stock: Chimpanzees could be hybrids of pre-gorillas and preaustralopithecines.

To account for the separation into distinct subspecies, a new decisive factor must be incorporated here, that of climate change.

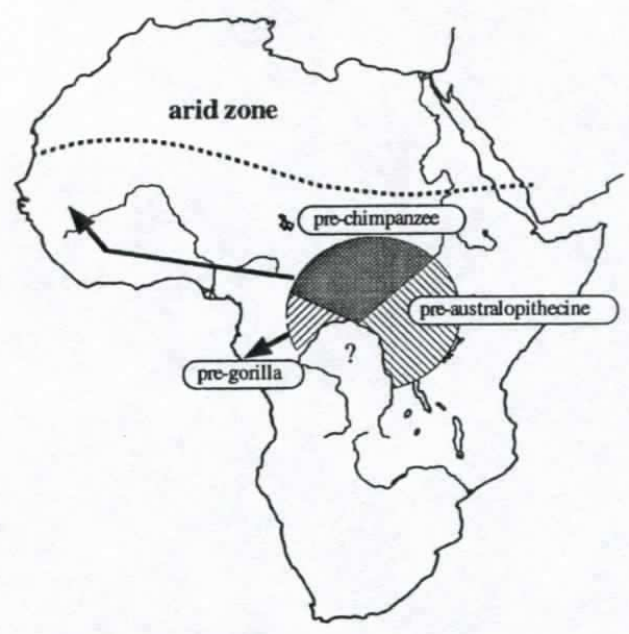

Fig. 6. Distribution of the common ancestor at the start of the polytypic phase. Pre-gorillas must have occupied the wet Atlantic monsoon zone (rain forest), pre-chimpanzees the less humid Atlantic monsoon zone (open forest) and pre-australopithecines the Indian Ocean monsoon zone (acacia savanna).

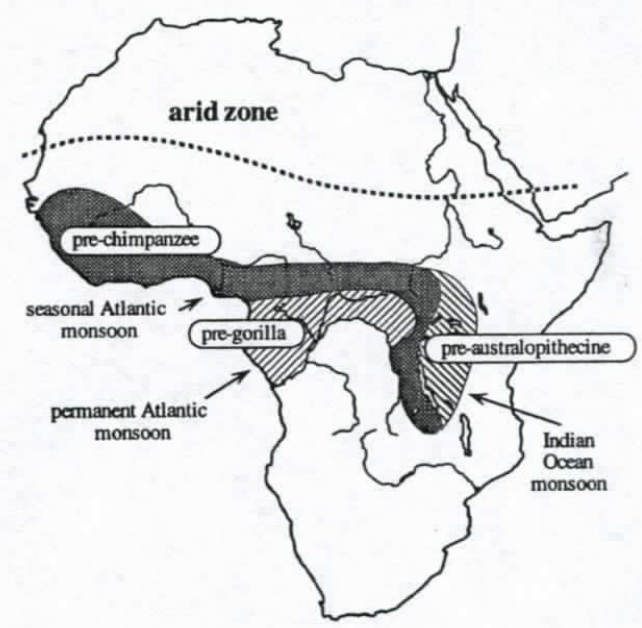

Fig. 7. Distribution of the common ancestor during the maximum extension of the polytypic phase. The prechimpanzee group must have been geographically centred around the present-day Lake Victoria region. It stretched to northwest Africa across the area north of the Zaire River in a forest-savanna mosaic or open woodland environment. The pre-gorilla group must have been located on the western edge of the former, still north of the Zaire River, in the very wet tropical rainforest zone. The pre-australopithecine group must have been located further east, in the East African Rift Valley, and further north in the savanna beyond the open forests inhabited by the pre-chimpanzees. 
The internalist approach in the climatic context

\section{Climate as the driving force of diversification of the common ancestor}

Climatic changes (Durand 1995) would have induced changes in the environment that must have been instrumental in the geographical isolation of the subspecies and species. Figures 6 and 7 explain the logic behind these changes.

The original common area of hominids in central Africa is currently a privileged climatic zone where the ITCZ (east-west) corresponding to the thermal and meteorological equator crosses the IOC (north-south) (Leroux 1983). Very schematically, we find the following features.

- The permanent Atlantic monsoon domain and tropical rainforest occur in the west; forest is documented in the Congo, Gabon and Cameroon basins from the onset of Miocene time (Boltenhagen et al. 1985).

- To the north lies the seasonal Atlantic monsoon domain and the savanna; in Nigeria a seasonal subtropical climate is reported to have existed since the Oligocene-Miocene boundary (Takashi \& Jux 1989).

- Further north still is the Sahara zone; evidence of a large arid zone in North Africa from mid-Miocene times is provided by rodents (Jaeger 1975) and by flora (Boureau et al. 1983).

- In the south and east is the domain of the Indian Ocean monsoons and trade winds. Tropical rainforest, open woodlands and mountain forests are reported to have coexisted since $19 \mathrm{Ma}$, and savannas and grasslands since 15-12 Ma (Bonnefille 1987; Retallack et al. 1990; Kingston et al. 1994). Local reliefs of the Rift Valley are superimposed on this background pattern to form an environmental mosaic that is sensitive to climatic fluctuations (White 1983; Pickford 1990).

Our hypothesis is that differentiation occurred in connection with the environment as determined by climate. Starting from a monotypic common stock (acquisition of seven chromosomal changes) (Figs 6 and 7), the pre-gorillas split away in the permanent monsoon domain north of the Zaire River barrier. The pre-chimpanzees spread widely east-west, on the northern boundary of the permanent Atlantic monsoon domain, ranging from Central to West Africa. The pre-australopithecines developed on the eastern margin under the influence of the Indian Ocean monsoons and trade winds, and spread north-south along the inter-oceanic confluence that roughly coincides with the eastern arm of the Rift Valley and westward across the savanna zone skirting the north of the tropical rainforest range. Such variations in climate could have segregated the three subspecies in a yet unknown history, as fossil remains dating from 12 to $5 \mathrm{Ma}$ are very sparse. Few finds have been made to date: a molar from Ngorora (Kenya) older than $10 \mathrm{Ma}$, one from Lukeino $(7 \mathrm{Ma})$ (Pickford 1975), a fragment of jaw with a molar from Lothagam, again in Kenya, dated to $5.5 \mathrm{Ma}$, and the Samburupithecus mandible (9.5 Ma).

A further implication concerns the shape of the pelvis. As gorillas and chimpanzees are quadrupeds, and as bipedalism is the apomorphic feature characteristic of australopithecines and their human descendants, the three components of the common ancestor must therefore still have walked on all fours.

\section{Climate as the driving force of diversification} of australopithecine, gorilla and chimpanzee species

Allopatric break-up of the ancestral form would have allowed gorillas, australopithecines and chimpanzees to become isolated (Fig. 8), as evidenced by the discovery of the earliest australopithecines (Ardipithecus ramidus), dated to some $4.4 \mathrm{Ma}$ in the Pliocene deposits of the Middle Awash (White et al. 1994, 1995).

Fossil finds of gorillas and chimpanzees will probably be few and far between, perhaps because of the lack of appropriate sedimentary environments in their tropical forest habitat, where remains are more rarely preserved than in open sedimentary environments of savannas. However, since becoming separate species, gorillas and chimpanzees have respectively acquired six autapomorphic chromosomal rearrangements (ch 1/4/5-17/8/10/14 for gorillas; ch $4 / 5 / 9 / 15 / 17 / 13$ for chimpanzees). It should also be pointed out that the bonobo (Pan paniscus) has autapomorphic rearrangements on chromosomes $2 \mathrm{q}$ and 7 . These autapomorphies prove the early isolation of gorillas and chimpanzees, and the probably more recent separation of the bonobo. It is interesting to see that the teeth of Ardipithecus ramidus of the Awash (size, morphology, enamel thickness) and 


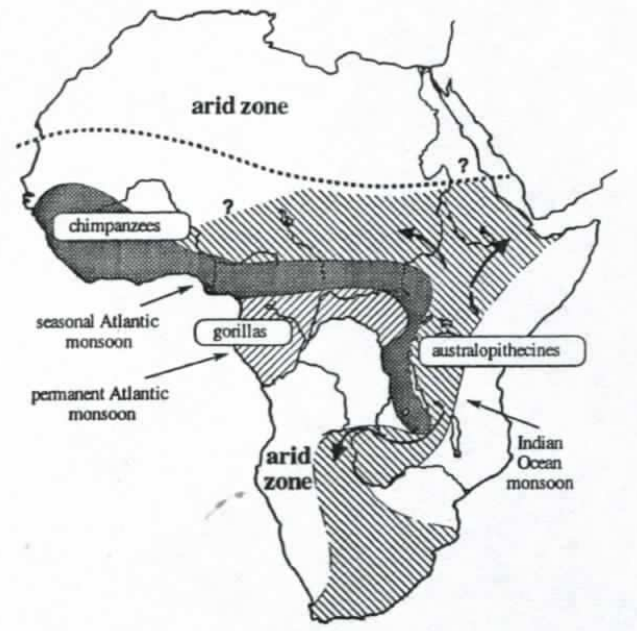

Fig. 8. Distribution of genera Pan, Gorilla and Australopithecus between 5 and $2 \mathrm{Ma}$. The chimpanzee lived north of the Zaire River in a forest-savanna mosaic or open woodland environment. The gorilla group must have been located on the western edge of the former, still north of the Zaire River, in the very wet tropical rainforest zone. The australopithecines group must have been located further east, in the East African Rift Valley, and further north in the savanna beyond the open forests inhabited by the chimpanzees, as suggested by the discovery of Koro Toro (Chad).

even features of the cranium have a strikingly chimpanzee-like morphology very similar to the bonobo, suggesting a possible filiation.

Climate and the environmental diversification it entails acted as controls over the area of distribution of the various species. Australopithecines were able to migrate from Central Africa northward to Ethiopia and the Afars, and southward, skirting round the Zambezi River barrier, to South Africa, where their fossils were first unearthed (Taung, Sterkfontein, Swartkrans) (Fig. 8).

The externalist approach implies that the earliest australopithecines could be found only to the east of the Rift Valley (Coppens 1986, 1994), and not to the west. The discovery of an early australopithecine, named 'Abel', (Australopithecus bahrelghazali), $2500 \mathrm{~km}$ west of the Rift Valley (Chad) and thought to be $3-3.5 \mathrm{Ma}$ old (Brunet et al. 1995, 1996) challenges this part of the theory. This discovery was, however, predictable by the trichotomic theory of the common ancestor in the internalist approach, as the acquisition of bipedal gait provided the potential to colonize all of the African savanna from north to south and east to west (Fig. 8).

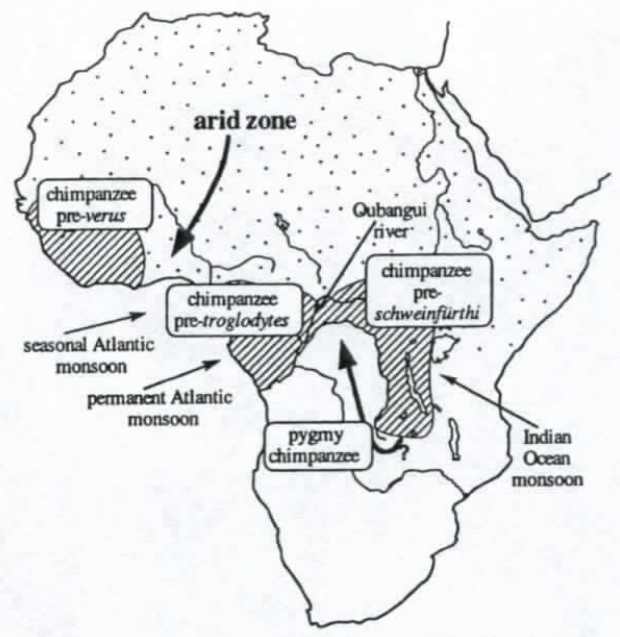

Fig. 9. Distribution of the three subspecies of common chimpanzees. The westernmost subspecies, the black chimpanzee (Pan troglodytes verus), inhabits Guinea whereas the others are found north of the Zaire or Congo River: the typical common chimpanzee (Pan troglodytes troglodytes) in the west in Congo, Gabon, Equatorial Guinea and Cameroon, and Schweinfürthi chimpanzee (Pan troglodytes schweinfurthi) further east in northern Zaire (after Collet 1988).

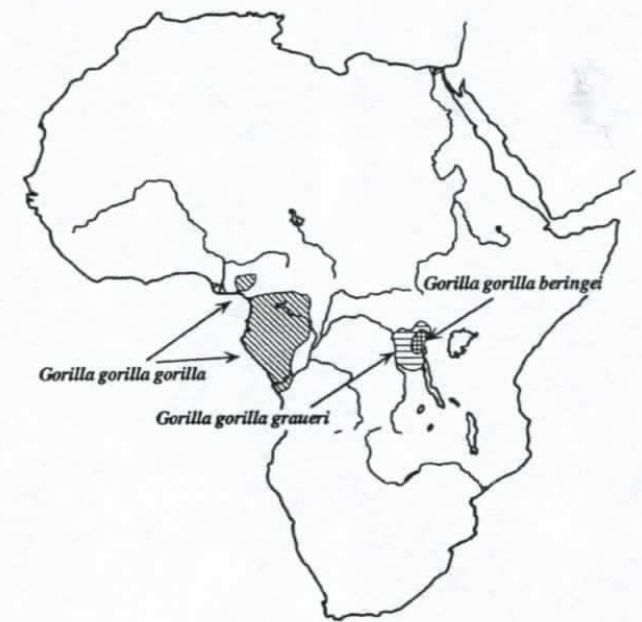

Fig. 10. Distribution of the three subspecies of gorillas. Gorillas are divided into western lowland gorillas (Gorilla gorilla gorilla) in Congo, Gabon, Equatorial Guinea and southern Cameroon, and eastern mountain gorillas (Gorilla gorilla graueri (Burundi and Rwanda); the third subspecies is the mountain gorilla of Rwanda and Uganda (Gorilla gorilla beringei) (after Collet 1988). 
Climate as the driving force of diversification of present gorilla and chimpanzee subspecies

The repetition of Pleistocene fluctuations is thought to be responsible for the current diversification of chimpanzees and gorillas, each characterized by three subspecies (Figs 9 and $10)$.

Starting from the initial chimpanzee distribution, it is thought that common chimpanzees then diversified into three subspecies. One subspecies (Pan troglodytes verus) is isolated in Guinea (Collet 1988), probably as a result of a break in the forest caused perhaps by a southward shift of the Sahara desert zone in Quaternary times engendering aridity in what is now Nigeria (Fig. 9). A second area is located in the Central African Republic and northern Zaire, along the Oubangui River, which already forms a natural barrier between the areas of distribution of western gorillas and chimpanzees (Gorilla gorilla gorilla and Pan troglodytes troglodytes) and eastern subspecies (Gorilla gorilla beringei and graueri as well as Pan troglodytes schweinfürthi) and which must have been reinforced by the southward extension of arid conditions.

This mechanism of separation of species into western and eastern populations may have been compounded because the gorilla and chimpanzee populations were unable to cross the great natural barrier of the marshland basin of the Zaire River.

It is impossible at present to provide details and a chronology of what might have happened, but this mechanism is plausible. It can, furthermore, be tested, because if it is correct, fossils of chimpanzees should be found in Tertiary deposits in areas where chimpanzees no longer occur from the Ivory Coast to Nigeria.

\section{Climate as the driving force of diversification of primitive and modern Homo.}

Climate plays a role in development of the species Homo erectus, which survived for at least one and a half million years and differentiated geographically, as indicated by the two opposing morphological trends observed in Homo erectus of Asia and of Europe, the latter giving rise to Neandertals. Climate also plays a further role in development of Homo sapiens, by determining clinal differences affecting characters related to climate, in particular pigmentation and various selected physiological factors (adaptations to altitude, humidity, aridity, etc.) (Lewontin 1982;
Langaney 1988). These differentiations must have been the same for the various geographical forms of Homo erectus.

Such adaptive differentiation can have occurred only in the last $180 \mathrm{ka}$ for Homo sapiens, which derived by cranio-facial contraction from a Homo erectus population. It is because this differentiation occurred so recently on the evolutionary scale that modern humans are alone in not being subdivided into geographically quantifiable and identifiable races.

\section{Conclusion: climate as a driving force of hominid evolution?}

The foregoing discussion shows that climate was instrumental in hominid evolution, but was it really a driving force behind it?

The externalist approach, with its claim that climate was responsible for the appearance of bipedalism, now seems to be ruled out by biological, palaeogeographical, palaeontological data and palaeoclimatic data on which it was based. The pattern of different environments in relation to the main climatic domains (permanent or seasonal Atlantic monsoon and Indian Ocean monsoon and trade winds) seems to have been comparable with the present-day situation since about $15 \mathrm{Ma}$, i.e. well before the formation of the Rift Valley ( $8 \mathrm{Ma}$ ).

Biological data do, however, support the embryonic origin of cranio-facial contraction, which determined the increase in cranial capacity and, through the position of the foramen magnum, brought about bipedalism. These processes are certainly partly under the control of so far unidentified homeobox genes (Hox genes) or other regulatory genes. The story of human evolution may be more appropriately termed an internalist history rather than an externalist one.

In the internalist approach, developmental biology is the major driving force behind hominid evolution but climate exerts a significant influence at crucial moments in that history: (1) in the prior development of ecological niches allowing the common ancestor (polytypical phase 2) to differentiate into three subspecific lineages foreshadowing the three present-day genera; (2) by facilitating relative fluctuations of the geographical areas of distribution of the various species, especially the extension of australopithecines towards the Sahara in the northwest, Ethiopia in the northeast, and into southern Africa; (3) by breaking up the area of distribution of extant species of gorillas and 
chimpanzees, which led to the three present-day subspecies of each; (4) by determining slight adaptive differences in pigmentation, which must have been the same for the various geographical forms of Homo erectus and Homo sapiens.

This work was supported by the UMR CNRS 5561 (Biogeosciences) and by the Laboratoire de Paléobiodiversité et Préhistoire de l'Ecole Pratique des Hautes Etudes (Université de Bourgogne, Dijon). We are grateful to two anonymous reviewers and to $\mathrm{M}$. Hart for helpful comments, to A. Bussière for the final drawings, and to C. Sutcliffe for help with translation.

\section{References}

Andrews, P. \& Cronin, J. E. 1982. The relationships of Sivapithecus and Ramapithecus and the evolution of the orangutan. Nature, 297, 541-546.

ANTHONY, J. 1952. La brisure de la base du crâne chez les Primates. Annales de Paléontologie, 38, 71-79.

Bailey, W. J., Fitch, D. H. A., Tagle, D. A., Czelusniak, J., Slightom, J. L. \& Goodman, M. 1991. Molecular evolution of the w-globin gene locus: gibbon phylogeny and the hominoid slowdown. Molecular Biology and Evolution, 8, 155-184. - Hayasaka, K., Skinner, C. G., Kehoe, S., Sieu, L. C., Slightom, J. L. \& Goodman, M. 1992. Reexamination of the African hominoid trichotomy with additional sequences from the primate $\beta$-globin gene cluster. Molecular Phylogenetics and Evolution, 1, 97-135.

Berger, A. 1992. Le climat de la Terre. De Boeck Université, Brussels.

Boltenhagen, E., Dejax, J. \& Salard-Cheboldaeff, M. 1985. Evolution de la végétation tropicale africaine du Crétacé à l'actuel d'après les données de la palynologie. Bulletin de la Section des Sciences, 8, 165-194.

BoNNEFILLE, R. 1987. Evolution des milieux tropicaux africains depuis le début du Cénozoïque. Mémoire des Travaux de l'Ecole Pratique des Hautes Etudes (EPHE), 17, 101-110.

Boureau, E., Cheboldaeff-Salard, M., Koeniguer, J. C. \& Louvet, P. 1983. Évolution des flores et de la végétation tertiaires en Afrique, au nord de l'équateur. Bothalia, 14, 355-367.

Brunet, M., Beauvilain, A., Coppens, Y., Heintz, E., Moutayea, H. E. \& Pilbeam, D. 1995. The first autralopithecine 2,500 kilometres west of the Rift Valley (Chad). Nature, 378, 273-274.

1996. Australopithecus bahrelghazali, une nouvelle espèce d'hominidé ancien de la région de Koro Toro (Tchad). Comptes Rendus de l'Académie des Sciences, Série IIa, 322, 907-913.

Carroll, S. B. 1995. Homeotic genes and the evolution of arthropods and chordates. Nature, 376, 479-485.

Chaline, J. 1994. Une famille peu ordinaire. Le Seuil, Paris.

- 1998. Vers une approche globale de l'évolution des Hominidés. Le Point sur-Comptes Rendus de l'Académie des Sciences, Serie II, 326, 307-318.

-, Dambricourt Malassé, A., Magniez-Jannin, F., Marchand, D., David, B., Millet, J.-J. \& CoURANT, F. 1998. Quantification de l'évolution morphologique des Hominidés et hétérochronies. Comptes Rendus de l'Académie des Sciences, Série II, 326, 291-298.

, Durand, A., Marchand, D., Dambricourt Malassé, A. \& Deshayes, M. J. 1996. Chromosomes and the origins of Apes and Australopithecines. Human Evolution, 11, 43-60.

- Dutrillaux, B., Couturier, J., Durand, A. \& MARCHAND, D. 1991. Un modèle chromosomique et paléobiogéographique d'évolution des primates supérieurs. Geobios, 24, 105-110.

Chiarelli, B. 1962. Comparative morphometric analysis of primate chromosomes of the anthropoid apes and man. Caryologia, 15, 99-121.

Chudeau, R. 1921. Les changements de climat du Sahara pendant le Quaternaire. Comptes Rendus de l'Académie des Sciences, 172, 604-607.

COLLET, J. Y. 1988. Les petits des grands singes. Terre sauvage. Nuit et Jour, 6-12.

Coppens, Y. 1986. Evolution de l'homme. Comptes Rendus de l'Académie des Sciences, 3(3), 227-243.

1994. Une histoire des Hominidés. Pour la Science, 201, 64-71.

Dambricourt Malassé, A. 1987. Ontogenèses, paléontogenèses et phylogenèse du corps mandibulaire catarhinien. Nouvelle interprétation de la mécanique humanisante (théorie de la foetilisation, Bolk, 1926). Thèse de Doctorat, Muséum National d'Histoire Naturelle, Paris.

1988. Hominisation et foetalisation. Comptes Rendus de l'Académie des Sciences, Série II, 307, 199-204.

1993. continuity and discontinuity during Hominization. Quaternary International, 29, 86-98.

1996. Nouveau regard sur l'origine de l'homme. La Recherche, 286, 46-54.

De Grouchy, J., Turleau, C., Roubin, M. \& Klein, M. 1972. Evolutions caryotypiques de l'homme et du chimpanzé. Étude comparative des topographies de bandes après dénaturation ménagée. Annales de Génétique, 15, 79-84.

Delattre, A. \& Fenart, R. 1954. Rotation occipitale positive et négative. Comptes Rendus de l'Académie des Sciences, 239, 676-678.

—_ \& 1956. L'hominisation du crâne estelle terminée? Comptes Rendus de l'Académie des Sciences, 243, 429-431.

— \& 1960. L'hominisation du crâne. CNRS, Paris.

de Menocal, P. B. 1995. Plio-Pleistocene African climate. Science, 270, 53-59.

DENIKER, J. 1885. Recherches anatomiques et embryologiques sur les singes anthropoïdes. Foetus de gorille et de gibbon comparés aux foetus humains et aux anthropoïdes jeunes et adultes. Archives de Zoologie expérimentale et générale, 2(3 bis), 1-265.

Deshayes, M. J. 1986. Croissance cranio-faciale et orthodontie. Masson, Paris.

1991. Reconsidération de la croissance cranio- 
faciale au cours de l'ontogenèse et de l'évolution. Implications pour les traitements orthopédiques. Revue d'Orthopédie dentofaciale, 25, 353-365.

1997. A new ontogenetic approach to craniofacial growth. The basis of Projet Télécrane International. Journal of Mastication and Health Society, 7(2), 59-76.

\& Dambricourt Malassé, A. 1990. Analyse des différents types architecturaux cranio-faciaux par l'approche ontogénique de l'hominisation. Revue de Stomatologie et de Chirurgie Maxillofaciale, 91, 149-258.

Devillers, C. \& Chaline, J. 1993. Evolution, an Evolving Theory. Springer, Berlin.

Diester-HaAss, L. \& Chamley, H. 1982. Oligocene and post-Oligocene history of sedimentation and climate off Northwest Africa (DSDP site 369). In: Von Rad, U., Hinz, K., Sarnthein, M. \& Seibold, E. (eds) Geology of the Northwest African Continental Margin. Springer, Berlin, 529-544.

Dollé, P., Dierich, A., Le Meur, M., Schimmang, T., Schubaur, B., Chambon, P. \& Duboule, D. 1993. Disruption of the Hoxd-13 gene induces localized heterochrony leading to mice with neotenic limbs. Cell, 75, 431-441.

DURAND, A. 1995. Sédiments quaternaires et changements climatiques au Sahel central (Niger et Tchad). Africa Geoscience Review, 2, 323-614.

Dutrillaux, B. \& Couturier, J. 1986. Principes de l'analyse chromosomique appliquée à la phylogénie: l'exemple des Pongidae et des Hominidae. Mammalia, 50, 22-37.

\& RichaRD, F. 1997. Notre nouvel arbre de famille. L'analyse des chromosomes permet de réécrire l'histoire des primates. La Recherche, 298, 54-61.

, Viegas-Pequignot, E. \& Couturier, J. 1986. Les méthodes cytogénétiques. Mammalia, 50, 11-20. Godfrey, L. \& MARKS, J. 1991. The nature and origins of primate species. Yearbook of Physical Anthropology, 34, 39-68.

Gonzalez, I. L., Sylvester, J. E., Smith, T. F., Stambolian, D. \& Schmickel, R. D. 1990. Ribosomal RNA gene sequences and hominoid phylogeny. Molecular Biology and Evolution, 7, 203-219.

Goodman, M., Bailey, W. J., Hayasaka, K., Stan. hope, M. J., Slightom, J. \& CZelusniak, J. 1994. Molecular evidence on primate phylogeny from DNA sequences. American Journal of Physical Anthropology, 94, 3-24.

Gould, S. J. 1977. Ontogeny and Phylogeny. Belknap Press of Harvard University Press, Cambridge, MA.

Hayasaka, K., Gojori, T. \& Horai, S. 1988. Molecular phylogeny and evolution of primate mitochondrial DNA. Molecular Biology and Evolution, 5, 626-644.

Hixson, J. E. \& Brown, W. M. 1986. A comparison of the small ribosomal RNA genes from the mitochondrial DNA of the great apes and humans: sequence, structure, evolution, and phylogenetic implications. Molecular Biology and Evolution, 3, 1-18.

Horai, S., Satta, Y., Hayasaka, K. et al. 1992. Man's place in Hominoidea revealed by mitochondrial DNA genealogy. Journal of Molecular Evolution, 35,
$32-43$.

Humphrey, R. R. 1967. Albino axolotls from an albino tiger salamander through hybridization. Journal of Heredity, 58, 95-101.

JAEGER, J. J. 1975. Les Muridae (Mammalia, Rodentia) du Pliocène et du Pléistocène du Maghreb. Origine; évolution; données biogéographiques et paléoclimatiques. Thèse de Doctorat, Université des Sciences et Techniques du Languedoc, Montpellier.

KING, M. C. \& Wilson, A. C. 1975. Evolution at two levels in humans and chimpanzees. Science, 188, 201-203.

Kingston, J. D., Marino, B. D. \& Hill, A. 1994. Isotopic evidence for Neogene hominid paleoenvironments in the Kenya Rift Valley. Science, 264, 955959.

Langaney, A. 1988. Les Hommes. Colin, Paris.

LeRoux, M. 1983. Le climat de l'Afrique tropicale. Champion, Paris.

Lewontin, R. 1982. La diversité des hommes. Belin, Paris.

Lipson, S. \& Pilbeam, D. 1982. Ramapithecus and hominid evolution. Journal of Human Evolution, 11, 545-548.

Maley, J. 1987. Fragmentation de la forêt dense humide africaine et extension des biotopes montagnards au Quaternaire récent: nouvelles données polliniques et chronologiques. Implications paléoclimatiques et biogéographiques. Palaeoecology of Africa, 17, 307-334.

MARKS, J. 1985. C-band variability in the common chimpanzee, Pan troglodytes. Journal of Human Evolution, 14, 669-675.

1993. Hominoid heterochromatin: terminal Cband as a complex genetic trait linking chimpanzee and gorilla. American Journal of Physical Anthropology, 90, 237-246.

Matera, A. G. \& Marks, J. 1993. Complex rearrangements in the evolution of hominoid chromosome XVII. Journal of Human Evolution, 24, 233-238.

McGinnis, W. \& Kuziora, M. 1997. Les gènes du développement. Pour la Science, hors série, 7614, 126-133.

Meyer, A. 1998. Hox gene variation and evolution. Nature, 391, 225-228.

Мiуamoto, M. M., Коop, B. F., Slightom, J. L., Goodman, M. \& Tennant, M. R. 1988. Molecular systematics of higher primates: genealogical relations and classification. Proceedings of the National Academy of Sciences of the USA, 85, 7627-7631.

, Slightom, J. L. \& Goodman, M. 1987. Phylogenetic relations of humans and African apes from DNA sequences in the $\psi \mathrm{n}$ globin region. Science, 238, 369-373.

Norris, D. O. \& GERN, W. A. 1976. Thyroxineinduced activation of hypothalamo-hypophysal axis in neotenic salamander larvae. Science, 194, 525.

PenNisi, E. \& Roush, W. 1997. Developing a new view of evolution. Science, 277, 34-37.

Perrin-Pecontal, P., Gouy, M., Nigon, V. M. \& Trabuchet, G. 1992. Evolution of the primate $\beta$ globin gene region: nucleotide sequence of the $\delta-\beta$ globin intergenic region of gorilla and phylogenetic relationships between African apes and man. Jour- 
nal of Molecular Evolution, 34, 17-30.

PickFord, M. 1975. Late Miocene sediments and fossils from the Northern Kenya Rift Valley. Nature, 256, 279-284

1990. Uplift of the Roof of Africa and its bearing on the evolution of mankind. Human Evolution, 5, 1-20.

Pruvolo, M. T., Disotell, T., Ammard, M. W. Brown, W. M. \& Honeycutt, R. L. 1991. Resolution of the African hominoid trichotomy using a mitochondrial gene sequence. Proceedings of the National Academy of Sciences of the USA, 88, 1570 1574.

RAFF, R. A. 1996. The Shape of Life. University of Chicago Press, Chicago, IL.

\& Kaufman, T. C. 1983. Embryos, Genes, and Evolution. MacMillan, New York.

Retallack, G. J., DuGas, D. P. \& Bestland, E. A. 1990. Fossil soils and grasses of a middle Miocene east African grassland. Nature, 247, 1325-1328.

Ruddiman, W. F. \& RAYMo, M. E. 1988. Northern Hemisphere climatic regimes during the past $3 \mathrm{Ma}$, possible tectonic connections. Philosophical transactions of the Royal Society of London, Series B, 318, 411-430.

Sarnthein, M., Thiede, J., Pflaumann, U. et al. 1982. Atmospheric and oceanic circulation patterns off Northwest Africa during the past 25 million years. In: Von RaD, U., Hinz, K., SARnthein, M. \& SeIBold, E. (eds) Geology of the North West African Continental Margin. Springer, Berlin, 545-604.

Scotese, C. R., Gahagan, L. M. \& Larson, R. L. 1988. Plate tectonic reconstructions of the Cretaceous and Cenozoic ocean basins. Tectonophysics, 155, 27-48.

Sibley, C. G., Comstock, J. A. \& Ahlquist, J. E. 1990. DNA hybridization evidence of hominoid phylogeny: a reanalysis of the data. Journal of Molecular Evolution, 30, 202-236.
Simons, E. L. 1989. Human origins. Science, 245, $1343-1350$.

SMOUSE, P. E. \& LI, W. H. 1987. Likelihood analysis of mitochondrial restriction-cleavage patterns for the human-chimpanzee-gorilla trichotomy. Evolution, 41, 1162-1176.

Stanyon, R. \& Chiarelli, B. 1981. The chromosomes of man and apes: evolution and comparison. Bionature, 1, 11-27.

\& \& 1982. Phylogeny of the Hominoidea: the chromosome evidence. Journal of Human Evolution, 11, 493-504.

\& 1983. Chromosomal phylogeny in great apes and humans. Antropologia Contemporanea, 6, 157-159.

TAKASHI, K. \& Jux, U. 1989. Palynology of Middle Tertiary lacustrine deposits from the Jos Plateau. Bulletin Nagasaki University of Natural Sciences, 29, 181-367.

Ueda, S., Watanabe, Y., Sartou, N. et al. 1989. Nucleotide sequences of immunoglobulin-epsilon pseudogenes in man and apes and their phylogenetic relationships. Journal of Molecular Biology, 205, 8590.

Voss, S. R. 1995. Genetic basis of paedomorphosis in the axolotl, Ambystoma mexicamum: a test of the single-gene hypothesis. Journal of Heredity, 86, 441447.

White, F. 1983. The Vegetation of Africa. UNESCO, Paris.

White, T. D., Suwa, G. \& Asfaw, B. 1994. Australopithecus ramidus, a new species of early hominid from Aramis, Ethiopia. Nature, 371, 306-312.

— \& 1995. Australopithecus ramidus, a new species of early hominid from Aramis, Ethiopia. Corrigendum. Nature, 375, 88.

YunISH, J. J. \& PraKash, O. 1982. The origin of man: a chromosomal pictorial legacy. Science, 215, 15251530 . 